\title{
Ruthenium(II) complexes with hydroxypyridinecarboxylates: Screening potential metallodrugs against Mycobacterium tuberculosis
}

\author{
Marília I.F. Barbosa ${ }^{\mathrm{a}}$, Rodrigo S. Corrêa ${ }^{\mathrm{a}}$, Lucas V. Pozzi ${ }^{\mathrm{a}}$, Érica de O. Lopes ${ }^{\mathrm{b}}$, Fernando R. Pavan ${ }^{\mathrm{b}}$, \\ Clarice Q.F. Leite $^{\mathrm{b}}$, Javier Ellena ${ }^{\mathrm{c}}$, Sérgio de P. Machado ${ }^{\mathrm{d}}$, Gustavo Von Poelhsitz ${ }^{\mathrm{e}, *}$, Alzir A. Batista ${ }^{\mathrm{a}, *}$ \\ a Departamento de Química, Universidade Federal de São Carlos, CEP: 13565-905 São Carlos (SP), Brazil \\ ${ }^{\mathrm{b}}$ Departamento de Ciências Biológicas, Faculdade de Ciências Farmacêuticas, Universidade Estadual Paulista, CEP: 14800-900, Araraquara (SP) Brazil \\ ${ }^{\mathrm{C} I n s t i t u t o ~ d e ~ F i ́ s i c a ~ d e ~ S a ̃ o ~ C a r l o s, ~ U n i v e r s i d a d e ~ d e ~ S a ̃ o ~ P a u l o, ~ C E P: ~ 13560-970 ~ S a ̃ o ~ C a r l o s ~(S P), ~ B r a z i l ~}$ \\ ${ }^{\mathrm{d}}$ Instituto de Química, Universidade Federal do Rio de Janeiro, CEP: 21941-590 Rio de Janeiro (RJ), Brazil \\ e Instituto de Química, Universidade Federal de Uberlândia, CEP: 38400-902 Uberlândia (MG), Brazil
}

\section{A R T I C L E I N F O}

\section{Article history:}

Received 31 July 2014

Accepted 29 August 2014

Available online 6 September 2014

\section{Keywords:}

Mycobacterium tuberculosis

Cytotoxicity

Ruthenium(II) complexes

Metallodrugs

Hydroxypyridinecarboxylates

\begin{abstract}
A B S T R A C T
Three promising antimycobacterium tuberculosis ruthenium(II) complexes with the deprotonated ligands 2-hydroxynicotinic acid (2-OHnicH), 6-hydroxynicotinic acid (6-OHnicH) and 3-hydroxypicolinic acid (3-OHpicH) were synthesized and characterized. Structural analysis revealed three different coordination modes depending of the hydroxypyridinecarboxylate ligand. In the complex $[\mathrm{Ru}(2-$ $\mathrm{OHnic})(\mathrm{dppb})(\mathrm{bipy})] \mathrm{PF}_{6}(\mathbf{1})$, the 2-OHnic anion is coordinated by the 0,0 -chelating mode (via carboxylate group and phenolate oxygen), in the $[\mathrm{Ru}(6-\mathrm{OHnic})(\mathrm{dppb})(\mathrm{bipy})] \mathrm{PF}_{6}(\mathbf{2})$ a $\mathrm{O}-\mathrm{O}$ chelation by the carboxylate group is observed for the 6-OHnic ligand and for the complex $[\mathrm{Ru}(3-\mathrm{OHpic})(\mathrm{dppb})(\mathrm{bipy})] \mathrm{PF}_{6}(\mathbf{3})$ a $\mathrm{N}, \mathrm{O}$-chelating mode (via carboxylate) occurs to the 3-OHpic anion. The compounds were evaluated for activity against Mycobacterium tuberculosis $\mathrm{H}_{37}$ Rv ATCC 27294 using Resazurin Microtitre Assay (REMA) plate method and cytotoxicity in VERO CCL- 81 cell line. All the synthesized compounds exhibited good antimycobacterial activity and a completely lack of cytotoxicity activity, indicating a good selectivity index.
\end{abstract}

(c) 2014 Elsevier Ltd. All rights reserved.

\section{Introduction}

Tuberculosis (TB) is a serious public health problem, one of the most dangerous infective disease world-wide. [1,2] Recent reports have estimated that about one third of the world population is infected with Mycobacterium tuberculosis (Mtb) [3]. The expanding number of multidrug resistant in the TB cases does not only create problems for the treatment but also the costs are ever-increasing [4-6]. According to the Global TB Control Report of the World Health Organization there are 300.000 new cases per year of tuberculosis multi-drug-resistant [3]. For these reasons the search for new chemicals with antimicrobial activity has increased [7-10]. In the last years, metal complexes have received considerable interest related to antitubercular applications [11-15]. In previous studies realized in our research group, ruthenium phosphine/diimine complexes were evaluated and provided evidence that they are potential agents against mycobacterial infections, specifically

\footnotetext{
* Corresponding authors. Tel.: +55 1633518285; fax: +55 1633518350

E-mail addresses: gustavo@iqufu.ufu.br (G.V. Poelhsitz), daab@ufscar.br (A.A. Batista).
}

against $M$. tuberculosis $\mathrm{H}_{37} \mathrm{Rv}$ [16,17]. Therefore, to obtain new active compounds, our present strategy was to use three isomeric ligands with potentially different coordination modes: 3-hydroxypicolinic acid (3-OHpicH), 2-hydroxynicotinic acid (2-OHnicH) and 6-hydroxynicotinic acid (6-OHnicH) (Scheme 1). Pyridinecarboxylic acids and their derivatives are present in many natural products, with interest in medicinal chemistry due to the wide variety of physiological properties displayed by the natural and also many synthetic derivatives. [18-20] 2-OHnicH and 6-OHnicH present tautomerism, both in the solid state and in solution (Scheme 1) [21]. These molecules can act as versatile ligands with distinct coordination behavior: monodentate, bridging, $\mathrm{N}-\mathrm{O}$ and $\mathrm{O}-\mathrm{O}$ chelating [22]. Some authors have described the ligand 2-OHnic coordinated to copper and cobalt complexes by phenolyc and carboxylic oxygen atoms [23]. On the other hand, 6-OHnic can coordinate by the carboxylate group [24], whereas, 3-hydroxypicolinate ligand exhibits $\mathrm{N}, \mathrm{O}$-chelation when coordinated with vanadium, silver and zinc metals [25-27].

In this paper, we report the synthesis, characterization, molecular structures, the in vitro antimycobacterial activity and cytotoxicity activity of three cationic $\mathrm{Ru}(\mathrm{II})$ complexes with 
formula $[\mathrm{Ru}(2-\mathrm{OHnic})(\mathrm{dppb})(\mathrm{bipy})] \mathrm{PF}_{6}$ (1), [Ru(6-OHnic)(dppb)(bipy)]PF 6 (2) and $[\mathrm{Ru}(3-\mathrm{OHpic})(\mathrm{dppb})(\mathrm{bipy})] \mathrm{PF}_{6}$ (3).

\section{Materials and methods}

\subsection{Materials and measurements}

All manipulations were performed under an inert atmosphere of purified argon using Schlenk techniques. Reagent grade solvents were appropriately distilled before use. The $\mathrm{RuCl}_{3} \quad 3 \mathrm{H}_{2} \mathrm{O}$ was purchased from Aldrich. The ligands 1,4-bis(diphenylphosphino)butane (dppb), 2,2'-bipyridine (bipy), 2-hydroxynicotinic acid, 6-hydroxynicotinic acid and 3-hydroxypicolinic acid were used as received from Aldrich. The cis-[ $\left.\mathrm{RuCl}_{2}(\mathrm{dppb})(\mathrm{bipy})\right] \mathrm{com}-$ plex was prepared according to published procedure [28].

NMR spectra were recorded on a Bruker 9.4 T instrument ( $400 \mathrm{MHz}$ for hydrogen frequency) for samples in $\mathrm{CH}_{2} \mathrm{Cl}_{2}$, using a capillary containing $\mathrm{D}_{2} \mathrm{O}$. The IR spectra of the powdered complexes were recorded from CsI pellets in the $4000-200 \mathrm{~cm}^{-1}$ region and were collected on a FTIR Bomem-Michelson 102 spectrometer. Cyclic voltammetry (CV) experiments were carried out at room temperature in $\mathrm{CH}_{2} \mathrm{Cl}_{2}$ containing $0.10 \mathrm{M} \mathrm{Bu}_{4} \mathrm{~N}^{+} \mathrm{ClO}_{4}$ (TBAP) (Fluka Purum), using a BAS-100B/W Bioanalytical Systems Instrument; the working and auxiliary electrodes were stationary Pt foils, a Lugging capillary probe was used and the reference electrode was $\mathrm{Ag} / \mathrm{AgCl}$. Microanalysis was performed by Microanalytical Laboratory of Universidade Federal de São Carlos, São Carlos (SP), using a Fisons CHNS, mod. EA 1108 elemental analyzer.

\subsection{Synthesis of ruthenium(II) complexes 1-3}

The hydroxypyridinecarboxylate complexes were synthesized by reaction of cis-[ $\mathrm{RuCl}_{2}(\mathrm{dppb})($ bipy $\left.)\right](0.132 \mathrm{mmol} ; 100 \mathrm{mg})$ with the corresponding $(0.132 \mathrm{mmol} ; 18.4 \mathrm{mg})$ ligands 2-hydroxynicotinic acid (2-OHnicH) (1), 6-hydroxynicotinic acid (6-OHnicH) (2) and 3-hydroxypicolinic acid (3-OHpicH) (3), in methanol $(20 \mathrm{~mL})$ under argon atmosphere, at room temperature, for $6 \mathrm{~h}$ in an 1:1 $\mathrm{M}$ ratio. The ligands were previously deprotonated with triethylamine $(0.14 \mathrm{mmol} ; 0.02 \mathrm{~mL})$ in methanol. The final orange solutions were concentrated to ca. $1 \mathrm{~mL}$ and $0.128 \mathrm{mmol}(21.0 \mathrm{mg})$ of<smiles>O=C(O)c1cccnc1O</smiles><smiles>O=C(O)c1ccc(O)nc1</smiles><smiles>O=C(O)c1ncccc1O</smiles>

2-OHnicH 6-OHnicH<smiles>O=C(O)c1ccc[nH]c1=O</smiles>

enol-keto tautomers of 2-OHnicH<smiles>O=C(O)c1ccc(=O)[nH]c1</smiles>

enol-keto tautomers of 6-OHnicH

Scheme 1. Structures of the ligands 2-OHnicH, 6-OHnicH and 3-OHpicH and the tautomeric equilibrium occurring in $2-\mathrm{OHnicH}$ and $6-\mathrm{OHnicH}$.
$\mathrm{NH}_{4} \mathrm{PF}_{6}$ solubilized in water $(5 \mathrm{~mL})$ was added for the precipitation of the complexes, in order to obtain orange precipitates. The solids were filtered off, well rinsed with water and diethyl ether, and dried in vacuo.

\subsubsection{Data for $[\mathrm{Ru}(2-\mathrm{OHnic})(\mathrm{dppb})($ bipy $)] \mathrm{PF}_{6}$ (1)}

Yield: $92 \mathrm{mg}$ (72\%). Anal. Calc. for $\mathrm{C}_{44} \mathrm{H}_{40} \mathrm{~F}_{6} \mathrm{~N}_{3} \mathrm{O}_{3} \mathrm{P}_{3} \mathrm{Ru}$ : exptl (calc) C, 54.47 (54.66); H, 4.14 (4.17); N, 4.28 (4.35). IR: greek letter $\mathrm{nu}(\mathrm{C}=\mathrm{O})(\mathrm{s})$ 1639, $\mathrm{nu}_{\mathrm{as}}\left(\mathrm{COO}^{-}\right)(\mathrm{m})$ 1594, $\mathrm{nu}_{\mathrm{s}}\left(\mathrm{COO}^{-}\right)(\mathrm{m})$ 1320, $\operatorname{beta}(\mathrm{N}-\mathrm{H}) \quad(\mathrm{w})$ 1554, $\quad \mathrm{nu}(\mathrm{C}=\mathrm{C}) \quad(\mathrm{m}) \quad 1435, \quad \mathrm{nu}(\mathrm{C}=\mathrm{N}) \quad(\mathrm{m})$ $1469 \mathrm{~cm}^{-1}, \mathrm{nu}_{\mathrm{as}} \mathrm{P}-\mathrm{F}(\mathrm{s})$ 841, gamaCH (m) 700, nu(Ru-N) (w) 547, $\mathrm{nu}_{\mathrm{s}}(\mathrm{P}-\mathrm{F})(\mathrm{m})$ 554, gama(N-H) (w) 518 and $\mathrm{nu}(\mathrm{Ru}-\mathrm{O})(\mathrm{w})$ $506 \mathrm{~cm}^{-1}$. ${ }^{1} \mathrm{H}$ NMR $\left(400.21 \mathrm{MHz}, \mathrm{CDCl}_{3}, 298 \mathrm{~K}\right): \delta(\mathrm{ppm}) 10.9(\mathrm{~s}$, $\mathrm{N}-\mathrm{H}$ of $2-\mathrm{OHnic}) ; 8.86\left(\mathrm{~d}, 1 \mathrm{H},{ }^{3} \mathrm{~J}=3.92 \mathrm{~Hz}\right) ; 8.57(\mathrm{~d}, 1 \mathrm{H}$, $\left.{ }^{3} J=7.5 \mathrm{~Hz}\right) ; 8.16\left(\mathrm{~d}, 1 \mathrm{H},{ }^{3} \mathrm{~J}=5.5 \mathrm{~Hz}\right) ; 7.96\left(\mathrm{~d}, 1 \mathrm{H},{ }^{3} \mathrm{~J}=4.7 \mathrm{~Hz}\right) ; 7.76$ $\left(\mathrm{d}, 1 \mathrm{H},{ }^{3} \mathrm{~J}=6.18 \mathrm{~Hz}\right) ; 7.68\left(\mathrm{t}, 1 \mathrm{H},{ }^{3} \mathrm{~J}=8.54 \mathrm{~Hz}\right) ; 7.53(\mathrm{t}, 1 \mathrm{H}$, $\left.{ }^{3} \mathrm{~J}=7.51 \mathrm{~Hz}\right) ; 7.11\left(\mathrm{t}, 1 \mathrm{H},{ }^{3} \mathrm{~J}=8.01 \mathrm{~Hz}\right) ; 6.68\left(\mathrm{~d}, 1 \mathrm{H},{ }^{3} \mathrm{~J}=6.91 \mathrm{~Hz}\right)$; $6.35\left(\mathrm{t}, 1 \mathrm{H},{ }^{3} \mathrm{~J}=7.00 \mathrm{~Hz}\right) ; 6.22\left(\mathrm{t}, 1 \mathrm{H},{ }^{3} \mathrm{~J}=6.96 \mathrm{~Hz}\right)$ (aromatic hydrogens for bipy and 2-OHnic); 7.85-6.00 (overlapped signals, $20 \mathrm{H}$ aromatic hydrogens for $\mathrm{dppb}) ; 3.8-1.5\left(8 \mathrm{H}, \mathrm{CH}_{2}\right.$ of $\left.\mathrm{dppb}\right)$.

\subsubsection{Data for $[\mathrm{Ru}(6-\mathrm{OHnic})(\mathrm{dppb})($ bipy $)] \mathrm{PF}_{6}$ (2)}

Yield: $100 \mathrm{mg}$ (78\%). Anal. Calc. for $\mathrm{C}_{44} \mathrm{H}_{40} \mathrm{~F}_{6} \mathrm{~N}_{3} \mathrm{O}_{3} \mathrm{P}_{3} \mathrm{Ru}$ : exptl (calc) C, 54.45 (54.66); H, 4.19 (4.17); N, 4.40 (4.35). IR: $\mathrm{nu}(\mathrm{C}=\mathrm{O})$ (s) 1709, $\mathrm{nu}_{\mathrm{as}}\left(\mathrm{COO}^{-}\right)(\mathrm{m}) 1639, \mathrm{nu}_{\mathrm{s}}\left(\mathrm{COO}^{-}\right)(\mathrm{m})$ 1338, beta(N-H) (w) 1598, $\mathrm{nu}(\mathrm{C}=\mathrm{C})(\mathrm{m})$ and $\mathrm{nu}(\mathrm{C}=\mathrm{N})(\mathrm{m}) 1440, \mathrm{nu}_{\mathrm{as}} \mathrm{P}-\mathrm{F}(\mathrm{s}) 844$, gamaCH (m) 700, nu(Ru-N) (w) 559, nu $\mathrm{s}_{\mathrm{s}}(\mathrm{P}-\mathrm{F})(\mathrm{m})$ 554, gama $(\mathrm{N}-\mathrm{H}) \quad(\mathrm{w}) \quad 520$ and $\mathrm{nu}(\mathrm{Ru}-\mathrm{O}) \quad(\mathrm{w}) \quad 502 \mathrm{~cm}^{-1} \cdot{ }^{1} \mathrm{H} \quad \mathrm{NMR}$ $\left(400.21 \mathrm{MHz}, \mathrm{CDCl}_{3}, 298 \mathrm{~K}\right): \delta$ (ppm) 12.7 (s, N-H of $6-\mathrm{OHnic}$ ); $8.09\left(\mathrm{~d}, 1 \mathrm{H},{ }^{3} \mathrm{~J}=6.35 \mathrm{~Hz}\right) ; 8.81\left(\mathrm{~d}, 1 \mathrm{H},{ }^{3} \mathrm{~J}=5.1 \mathrm{~Hz}\right) ; 8.57(\mathrm{t}, 1 \mathrm{H}$, ${ }^{3} \mathrm{~J}=7.2 \mathrm{~Hz}$ ); $8.31(\mathrm{~m}) ; 8.13(\mathrm{~m}) ; 7.83-6.94(\mathrm{~m})$ (aromatic hydrogens for bipy and 6-OHnic); 6.85-6.00 (overlapped signals, $20 \mathrm{H}$ aromatic hydrogens for $\mathrm{dppb}) ; 4.0-1.0\left(8 \mathrm{H}, \mathrm{CH}_{2}\right.$ of $\left.\mathrm{dppb}\right)$.

\subsubsection{Data dor $[R u(3-O H p i c)(d p p b)($ bipy $)] P F_{6}$ (3)}

Yield: $115 \mathrm{mg}$ (90\%). Anal. Calc. for $\mathrm{C}_{44} \mathrm{H}_{40} \mathrm{~F}_{6} \mathrm{~N}_{3} \mathrm{O}_{3} \mathrm{P}_{3} \mathrm{Ru}$ : exptl (calc) C, 54.50 (54.66); H, $4.10(4.17) ; \mathrm{N}, 4.44$ (4.35). IR: = nu(C=O) (s) $1641, \mathrm{nu}_{\mathrm{as}}\left(\mathrm{COO}^{-}\right)(\mathrm{m}) 1600, \mathrm{nu}_{\mathrm{s}}\left(\mathrm{COO}^{-}\right)(\mathrm{m}) 1307, \mathrm{nu}(\mathrm{C}=\mathrm{C})(\mathrm{m})$ 1462, nu(C=N) (m) $1434 \mathrm{~cm}^{-1},{ }_{n u a s} \mathrm{P}-\mathrm{F}(\mathrm{s}) 844$, gamaCH $(\mathrm{m}) 700$, $\mathrm{nu}_{\mathrm{s}}(\mathrm{P}-\mathrm{F})(\mathrm{m})$ 559, nu(Ru-O) (w) 504 and nu(Ru-O) (w) $409 \mathrm{~cm}^{-1}$. ${ }^{1} \mathrm{H}$ NMR $\left(400.21 \mathrm{MHz}, \mathrm{CDCl}_{3}, 298 \mathrm{~K}\right): \delta$ (ppm) 12.6 (s, O-H of 3-OHpic); $\quad(\mathrm{ppm}) \quad 8.98 \quad\left(\mathrm{~d}, 1 \mathrm{H}, \quad{ }^{3} \mathrm{~J}=4.96 \mathrm{~Hz}\right) ; 8.26 \quad(\mathrm{~d}, \quad 1 \mathrm{H}$, $\left.{ }^{3} J=4.5 \mathrm{~Hz}\right) ; 8.20\left(\mathrm{~d}, 1 \mathrm{H},{ }^{3} \mathrm{~J}=6.9 \mathrm{~Hz}\right) ; 8.07\left(\mathrm{~d}, 1 \mathrm{H},{ }^{3} \mathrm{~J}=7.56 \mathrm{~Hz}\right) ; 8.0$ $\left(\mathrm{t}, 1 \mathrm{H},{ }^{3} \mathrm{~J}=7.41 \mathrm{~Hz}\right) ; 7.88\left(\mathrm{~d}, 1 \mathrm{H},{ }^{3} J=5.89 \mathrm{~Hz}\right) ; 7.70(\mathrm{t}, 1 \mathrm{H}$, $\left.{ }^{3} J=7.23 \mathrm{~Hz}\right) ; 7.59\left(\mathrm{~d}, 1 \mathrm{H},{ }^{3} \mathrm{~J}=7.66 \mathrm{~Hz}\right) ; 7.46\left(\mathrm{t}, 1 \mathrm{H},{ }^{3} \mathrm{~J}=7.19 \mathrm{~Hz}\right)$; $7.37\left(\mathrm{t}, 1 \mathrm{H},{ }^{3} \mathrm{~J}=7.11 \mathrm{~Hz}\right.$ ) (aromatic hydrogens for bipy and 3-OHpic); 7.32-6.09 (overlapped signals, $20 \mathrm{H}$ aromatic hydrogens for dppb); 3.3-1.5 (8H, $\mathrm{CH}_{2}$ of dppb).

\subsection{X-ray crystallography analysis and data collection}

Crystals of the complexes were grown at room temperature by slow evaporation of methanol/dichloromethane solutions. The crystals were mounted on an Enraf-Nonius Kappa-CCD diffractometer with graphite monochromated Mo $\mathrm{K} \alpha(\lambda=0.71073 \AA)$ radiation. The final unit cell parameters were based on all reflections. Data collections for three complexes were carried out at room temperature $(293 \mathrm{~K})$, with the COLLECT program [29]; integration and scaling of the reflections were performed with the HKL DenzoScalepack system of programs [30]. The crystal structures were solved by the Direct method using sHeLxs-97 [31] and refined anisotropically (non-hydrogen atoms) by full-matrix least-squares on $F^{2}$ using a SHELXL-97 [32] program. A Gaussian method implemented was used for the absorption corrections [33]. All hydrogen atoms were positioned stereochemically and refined using the riding model. 
Furthermore, a positional disorder in the $\mathrm{PF}_{6}^{-}$anion of the complex 3 can be reliably modeled. This disorder was refined over two occupancy sites for each atom of fluorine. The program ORTEP-3 [34] was used for drawing the molecules. WINGX was used to prepare materials for publication. The main crystal, collection and structure refinement data for complexes 1-3 are summarized in Table 4.

\subsection{Theoretical calculations}

The geometry optimization was performed using a i-7 computer, with a GAUSSIAN 09 program with the B3LYP hybrid density functional combined with the $6-31 \mathrm{G}(\mathrm{d}, \mathrm{p})$ and LACVP basis set for $\mathrm{Ru}$ atoms [35]. The calculation of frequencies used to find the minimum geometries does not have imaginary values.

\subsection{Anti-M. tuberculosis activity assay}

The anti-MTB activity of the compounds was determined by the Resazurin Microtiter Assay (REMA) [36]. Stock solutions of the test compounds were prepared in dimethyl sulfoxide (DMSO) and diluted in Middlebrook 7H9 broth (Difco), supplemented with oleic acid, albumin, dextrose and catalase (OADC enrichment - BBL/Becton Dickinson, Sparks, MD, USA), to obtain final drug concentration ranges from 0.05 to $25 \mu \mathrm{g} / \mathrm{mL}$. The serial dilutions were realized in a Precision XS Microplate Sample Processor (Biotek ${ }^{\mathrm{tm}}$ ). The isoniazid was dissolved in distilled water, as recommended by the manufacturer (Difco laboratories, Detroit, MI, USA), and used as a standard drug. MTB $\mathrm{H}_{37}$ Rv ATCC 27294 was grown for 7 to 10 days in Middlebrook 7H9 broth supplemented with OADC, plus $0.05 \%$ Tween 80 to avoid clumps. Cultures were centrifuged for $15 \mathrm{~min}$ at 3,150 x g, washed twice, and resuspended in phosphate-buffered saline and aliquots were frozen at $-80^{\circ} \mathrm{C}$. After 2 days, an aliquot was thawed to determine the viability and the Colony-Forming Unit (CFU) after freezing. MTB $\mathrm{H}_{37} \mathrm{Rv}$ was thawed and added to the test compounds, yielding a final testing volume of $200 \mu \mathrm{L}$ with $2 \times 10^{4} \mathrm{CFU} / \mathrm{mL}$. Microplates with serial dilutions of each compound were incubated for 7 days at $37^{\circ} \mathrm{C}$, after resazurin was added to test viability. Wells that turned from blue to pink, with the development of fluorescence, indicated growth of bacterial cells, while maintenance of the blue colour indicated bacterial inhibition [36,37]. The fluorescence was read (530 nm excitation filter and $590 \mathrm{~nm}$ emission filter) in a SPECTRAfluor Plus $\left(\right.$ Tecan $\left.^{\circledR}\right)$ microfluorimeter. The MIC was defined as the lowest concentration resulting in $90 \%$ inhibition of growth of MTB [37] As a standard test, the MIC (minimal inhibitory concentration) of isoniazid was determined on each microplate. The acceptable range of isoniazid MIC is from 0.015 to $0.06 \mu \mathrm{g} / \mathrm{mL}[36,37]$. Each test was set up in triplicate.

Table 4

MIC values of antimycobacterial activity of ruthenium complexes, free ligands and reference drugs.

\begin{tabular}{lll}
\hline Compound & MIC $(\mathrm{g} / \mathrm{mL})$ & MIC $(\mathrm{M})$ \\
\hline 2-OHnicH & $>50$ & $>359.4$ \\
6-OHnicH & $>50$ & $>359.4$ \\
3-OHpicH & 31.5 & 226.4 \\
bipy & 25.0 & 169.1 \\
dppb & 50 & 117.2 \\
cis-[RuCl $(\mathrm{dppb})(\mathrm{bipy})]$ & 3.9 & 5.1 \\
$\mathbf{1}$ & 0.39 & 0.4 \\
$\mathbf{2}$ & 6.3 & 6.4 \\
$\mathbf{3}$ & 3.1 & 3.2 \\
isoniazid & 0.03 & 0.4 \\
ethambutol & 20.7 & 5.6 \\
gatifloxacin & 3.3 & 0.9 \\
\hline
\end{tabular}

\subsection{In vitro cytotoxicity assay}

Vero line (ATCC ${ }^{\circledR} C C L-81^{\mathrm{TM}}$ ) was used to determine cytotoxicity $\left(\mathrm{IC}_{50}\right)$. The cells were kept incubated at $37{ }^{\circ} \mathrm{C}$ with $5 \% \mathrm{CO}_{2}$ surface in plates with $12.50 \mathrm{~cm}^{2}$, containing $10 \mathrm{~mL}$ of DMEM (Vitrocell ${ }^{\circledR}$ ) medium culture supplemented with $10 \%$ fetal bovine serum, gentamicin sulfate $(50 \mathrm{mg} / \mathrm{L})$ and amphotericin B $(2 \mathrm{mg} / \mathrm{L})$.This technique consists in collecting the cells using a solution of trypsin/ EDTA (Vitrocell ${ }^{\circledR}$ ), centrifugation (2000 rpm for $5 \mathrm{~min}$ ) and counting the number of cells in Newbauer chamber adjusting to $3.4 \times 10^{5}$ cells $/ \mathrm{ml}$ in DMEM. This suspension was deposited on each well $200 \mu \mathrm{L}$ of a 96-well microplate obtaining a cell concentration of $6.8 \times 10^{4}$ cells/well and incubated at $37^{\circ} \mathrm{C}$ in an atmosphere of $5 \% \mathrm{CO}_{2}$ for $24 \mathrm{~h}$ for cell attachment to the plate. The following dilutions of test compounds were prepared so as to obtain concentrations from 500 to $1.95 \mu \mathrm{g} / \mathrm{mL}$. The dilutions were added to the cells after the removal of any medium and cells that did not adhere, and incubated again for $24 \mathrm{~h}$. The cytotoxicity of the compounds was determined by adding $30 \mu \mathrm{L}$ of resazurin and read after $6 \mathrm{~h}$ of incubation. The reading was performed in microplate Spectrafluor Plus $\left(\right.$ TECAN $^{\circledR}$ ) reader using excitation and emission filters at wavelengths of 530 and $590 \mathrm{~nm}$ respectively. The cytotoxicity $\left(\mathrm{IC}_{50}\right)$ was defined as the highest concentration of compound able of allowing the viability of at least $50 \%$ of the cells.

\subsection{Selectivity index}

The selectivity index (SI) of the metal complexes was calculated by dividing the $\mathrm{IC}_{50}$ for the Vero cells by the MIC for the pathogen. The higher the value of SI the agent analyzed is more active against the tuberculosis bacillus and less cytotoxic to the host, being considered as a promising substance that with SI higher than 10 .

\section{Results and discussion}

\subsection{Synthesis and crystallography}

The chemical reactivity of the deprotonated hydroxypyridinecarboxylates ligands with the precursor cis-[ $\left.\mathrm{RuCl}_{2}(\mathrm{dppb})(\mathrm{bipy})\right]$ enabled the synthesis of complexes with general formula $\left[\mathrm{Ru}(\mathrm{L})(\mathrm{dppb})(\right.$ bipy)$] \mathrm{PF}_{6}, \mathrm{~L}=$ 2-OHnic; 6-OHnic; 3-OHpic, containing three chelated ligands, under mild conditions, by simple chloride exchange (Scheme 2). The orange ruthenium(II) hydroxypyridinecarboxylates complexes were isolated, as pure solids, from methanol, in good yields. The elemental analyses of the complexes are described in experimental section and they agree well with the proposed formulations. The molar conductance values measured in methanol at room temperature vary from 70.0 to $90.0 \mathrm{~S} \mathrm{~cm}^{2}$ $\mathrm{mol}^{-1}$, revealing the 1:1 electrolytic nature [38] of the 1-3 complexes with the hydroxypyridinecarboxylate molecules acting as monocharged bidentates ligands in all cases.

The crystal structures of complexes 1-3 were determined by single crystal X-ray diffraction. ORTEP diagrams [34] of the complexes with the main labeled atoms are shown in Figs. 1-3, together with selected bonds and angles lengths. Utilizing the crystallographic data was possible to confirm the coordination mode of ligands 2-OHnic and 6-OHnic in the keto tautomeric form, respectively in complexes $\mathbf{1}$ and $\mathbf{2}$. Also was confirmed that the 2-OHnic ligand is coordinated to $\mathrm{Ru}(\mathrm{II})$ by the carboxylate and phenolate oxygens, forming a 6-membered chelating ring, while the 6-OHnic ligand is coordinated through carboxylate oxygens to form a 4membered chelating ring. In complex 3 the 3-OHpic ligand showed a $\mathrm{N}-\mathrm{O}$ (oxygen from carboxylate) coordination mode forming a five-membered chelate ring. 

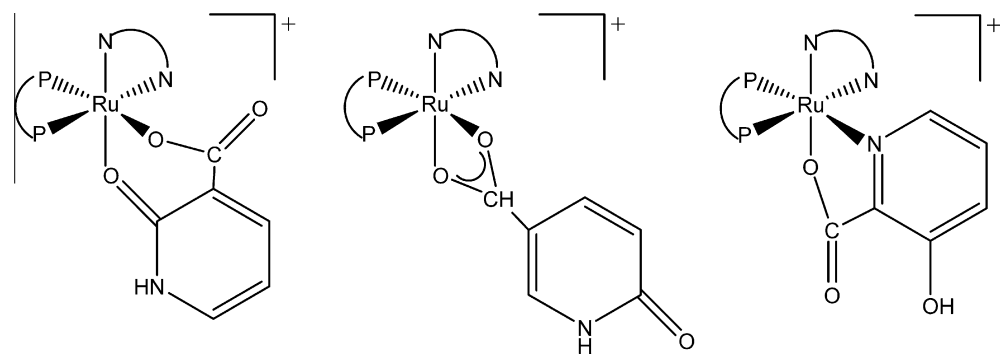

Scheme 2. Different coordination modes for the 2-OHnic, 6-OHnic and 3-OHpic ligands in complexes 1-3, respectively.

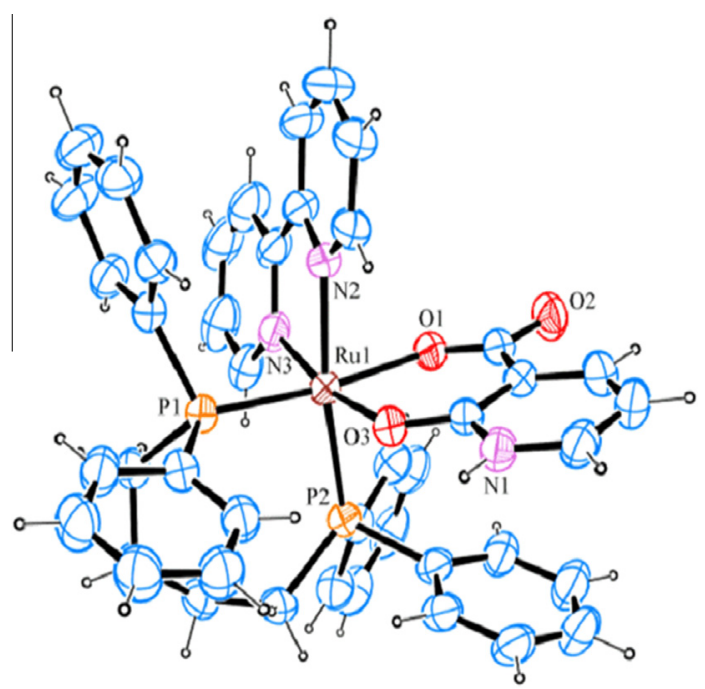

Fig. 1. Molecular structure of the cation $[\mathrm{Ru}(2-\mathrm{OHnic})(\mathrm{dppb})(\mathrm{bipy})]^{+}$in $\mathbf{1}$. Hydrogens atoms, non-coordinated anions and the methanol molecule in the crystal lattice are omitted for clarity. Selected bond lengths $[\AA ̊]$ and angles $\left[{ }^{\circ}\right]$ : Ru1-N3 2.052(4), Ru1-N2 2.107(3), Ru1-O3 2.091(3), Ru1-01 2.124(2), Ru1-P1 2.300(1), Ru1-P2 2.318(1), O2-C1 1.239(5), O3-C3 1.269(4), C1-O1 1.265(5); P1-Ru1-P2 96.56(4), O3-Ru1-O1 86.86(10), N3-Ru1-N2 78.78(17), N3-Ru1-O3 168.76(13), O1-Ru1-P1 173.20(8), N2-Ru1-P2 171.41(8).

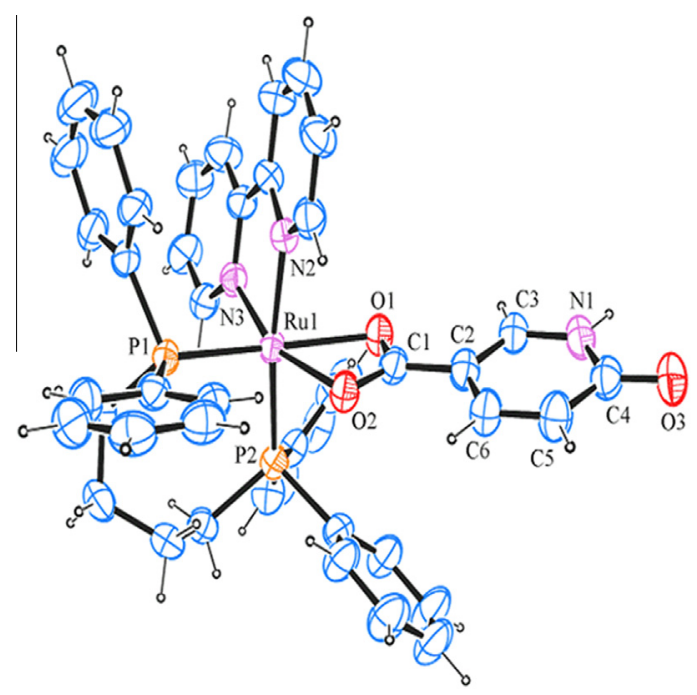

Fig. 2. Molecular structure of the cation $[\mathrm{Ru}(6-\mathrm{OHnic})(\mathrm{dppb})(\mathrm{bipy})]^{+}$in 2 . Hydrogens atoms, non-coordinated anions and the dichloromethane molecule in the crystal lattice are omitted for clarity. Selected bond lengths $[\AA]$ and angles $\left[^{\circ}\right]:$ Ru1N3 2.054(3), Ru1-N2 2.089(3), Ru1-O2 2.210(2), Ru1-01 2.136(2), Ru1-P1 2.284(9), Ru1-P2 2.328(9), O2-C1 1.272(4), O3-C4 1.239(4), 01-C1 1.282(4); P1Ru1-P2 98.37(3), O2-Ru1-O1 60.73(9), N3-Ru1-N2 78.76(11), N3-Ru1-O2 101.32(10), O1-Ru1-P1 108.39(7), N2-Ru1-P2 170.73(8).

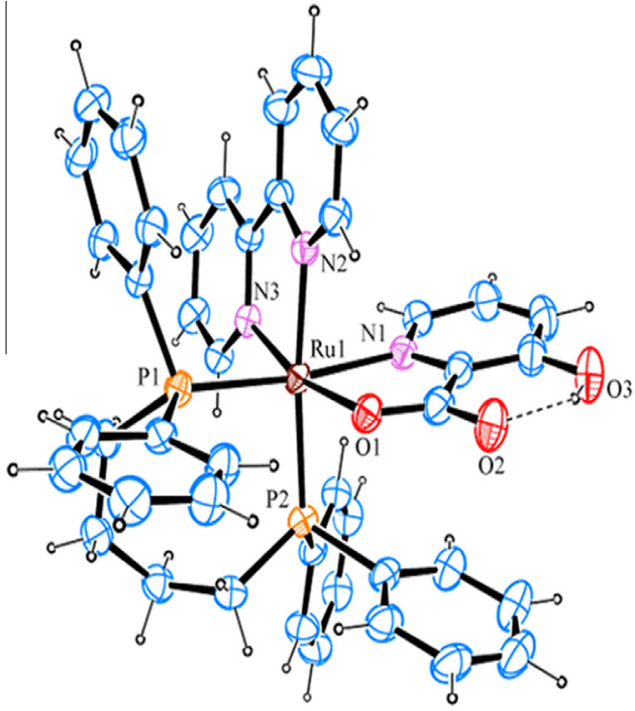

Fig. 3. Molecular structure of the cation $[\mathrm{Ru}(3-\mathrm{OHpic})(\mathrm{dppb})(\mathrm{bipy})]^{+}$in $\mathbf{3}$. Hydrogens atoms and non-coordinated anions are omitted for clarity. Selected bond lengths $[\AA ̊]$ and angles []: Ru1-N3 2.068(2), Ru1-N2 2.084(2), Ru1-01 2.104(2), Ru1-N1 2.317(2), Ru1-P1 2.337(1), Ru1-P2 2.344(1), O2-C1 1.248(4), O3-C3 1.325(4), O1-C1 1.276(4); P1-Ru1-P2 93.90(3), O1-Ru1-N1 78.25(9), N3-Ru1-N2 78.50(9), N3-Ru1-O1 166.54(9), N1-Ru1-P1 172.60(7), N2-Ru1-P2 174.02(7).

In complex 1 the asymmetric unit consists of a cationic complex with a $\mathrm{PF}_{6}^{-}$as counter-ion and methanol as solvate which stabilize the crystal structure with the ruthenium center, adopting a distorted octahedral coordination geometry formed by three bidentate ligands. The complex consists structurally of a bidentate phosphine (dppb) trans to a nitrogen atom of bipy and to one of the carboxylate oxygen atoms, the other bipy nitrogen is trans to the hydroxyl oxygen of 2-OHnic ligand, as showed in Fig. 1. The crystal structure of this complex is stabilized by hydrogen bonds involving the $\mathrm{PF}_{6}^{-}$anion and the complex forming $\mathrm{C}-\mathrm{H} \ldots \mathrm{F}$ contacts, and also the methanol molecule with the complex resulting in a classical $01 \mathrm{~s}-\mathrm{H} 1 \mathrm{~s} \ldots \mathrm{O} 2$ hydrogen bond separated by $2.038 \AA$, O1s...02 (donor ...acceptor) distance of $2.693 \AA$ and forming an O1a-H1s...O2 angle of $136.77^{\circ}$ (Fig. S1). In complex 2 the 6-OHnic ligand, Fig. 2, showed a $\mathrm{O}-\mathrm{O}$ chelation through the carboxylate with a small bite angle $\left(\mathrm{O}-\mathrm{Ru}-\mathrm{O}=60.73(9)^{\circ}\right)$. The bond distances C1-O1 and $\mathrm{C} 1-02$ from the carboxylate group are 1.282 (4) and 1.272 (4) A, respectively, showing the electron delocalization associated with the chelation. The coordination of the 6-OHnic as the keto tautomeric form in this complex was confirmed analyzing the C4-03 distance [1.239 (4) Å], showing a double bond character. In this crystal structure it is observed a strong $\mathrm{N} 1-\mathrm{H} 1 \ldots \mathrm{O} 3$ interaction at distance of $1.915 \AA$ and angle of $174.71^{\circ}$ forming centrosymmetric dimmers, with N1…03 separation of $2.772 \AA$. Also there are $\mathrm{C}-\mathrm{H} \cdots \mathrm{F}$ contacts bridging the molecules of this complex (Fig. S2). 
In complex 3 one $\mathrm{PF}_{6}^{-}$anion and a $\mathrm{CH}_{2} \mathrm{Cl}_{2}$ molecule are present in the asymmetric unit. As shown in Fig. 3, in this structure the phosphorus atoms are disposed trans to nitrogen atoms, one from the bipy ligand, and other from the 3-OHpic ligand. The oxygen atom of the carboxylate group is positioned trans to the remaining bipy nitrogen atom. The C1-O1 bond distance of 1.276 (4) $\AA$, indicates a single bond character of the coordinated oxygen from carboxylate group, which is negatively charged. In this structure is observed intramolecular hydrogen bond forming a six-membered ring. This $03-\mathrm{H} 3 \ldots \mathrm{O} 2$ interaction presents a distance of $1.847 \AA$ and angle of $147.04^{\circ}$ with $03 \ldots 02$ separation of $2.568 \AA$. Such characteristic is also observed in the free 2-OHnicH ligand [23]. The structure of $\mathbf{3}$ shows $\mathrm{C}-\mathrm{H} \ldots \mathrm{O}$ intermolecular contacts linking the molecules of the complex and $\mathrm{C}-\mathrm{H}$...F contacts (Fig. S3) that are present in all the crystal structures from this work.

\subsection{Spectroscopical characterization}

In the ${ }^{31} \mathrm{P}\left\{{ }^{1} \mathrm{H}\right\}$ NMR spectra of the complexes $\mathbf{1}$ and $\mathbf{2}$ two doublets were observed, indicating the presence of two inequivalent phosphorus atoms (Table 1), while for compound 3 only one singlet was observed. The signals, in the region of $39.0-50.3 \mathrm{ppm}$, are consistent with a geometry where one of the nitrogens of the bipyridine is trans to one phosphorus atom of dppb for the three complexes [39], and the second is trans to oxygen of carboxylate group (complexes $\mathbf{1}$ and $\mathbf{2}$ ). In complex 3, it is attributed that the pyridinic nitrogen of 3-OHpic ligand is trans to a phosphorus atom, resulting in a coalescence of the signals caused by the similarity of the nitrogen atoms of bipy and 3-OHpic ligands. When the ${ }^{31} \mathrm{P}\left\{{ }^{1} \mathrm{H}\right\}$ NMR spectrum of 3 was obtained in $\mathrm{CDCl}_{3}$, instead $\mathrm{CH}_{2} \mathrm{Cl}_{2} / \mathrm{D}_{2} \mathrm{O}$ capillary, the two expected doublets signals were observed (Fig. 4, Table 2). Such effect is due to the solvent ability of modifying the multiplicity and sensitive characteristics of the phosphorus atoms from the dppb ligand and has been observed for similar compounds [40].

In the ${ }^{1} \mathrm{H}$ NMR spectra of complexes $\mathbf{1}$ and $\mathbf{2}$ were observed singlet signals at $\delta 10.9$ and $12.7 \mathrm{ppm}$, respectively. These are assigned to the protonated form of the pyridinic nitrogen, indicating that the ligands 2-OHnic and 6-OHnic coordinate to metal in the keto form [24], as showed in Scheme 2.

\subsection{Electrochemical studies}

The cyclic voltammograms of complexes 1-3 showed a quasi-reversible process $\left(i_{\mathrm{pa}} / i_{\mathrm{pc}} \sim 1.1\right)$ attributed to the $\mathrm{Ru}^{\mathrm{II}} / \mathrm{Ru}^{\mathrm{III}}$ oxidation (between $1.30 \mathrm{~V}$ and $1.35 \mathrm{~V}$ ) followed by the $\mathrm{Ru}^{\mathrm{III}} / \mathrm{Ru}^{\mathrm{II}}$ reduction (between 1.21 and $1.29 \mathrm{~V}$ ) as showed in Table 3. These data indicates little electronic difference among the complexes despite the different coordination modes of the hydroxypyridinecarboxylates ligands in complexes 1-3. The $E_{1 / 2}$ value for the precursor cis-[ $\left.\mathrm{RuCl}_{2}(\mathrm{dppb})(\mathrm{bipy})\right]$ was observed at $0.60 \mathrm{~V}$ [28] clearly indicating that the substitution of two monoanionic chlorides by a single monocharged chelating 2-OHnic, 6-OHnic or 3-OHpic stabilizes the $\mathrm{Ru}(\mathrm{II})$ metallic center by approximately $0.70 \mathrm{~V}$.

\subsection{Theoretical calculations}

As suggested by DFT calculation, the HOMOs of complexes 1-3 present strong participation of the $d$ orbitals of the Ru atom and of the hydroxypyridinecarboxylates ligands. This was also previously observed by other ruthenium/diphosphine complexes synthesized in our laboratory [41]. The LUMOs are essentially the same for all complexes 1-3, with great participation of bipyridine orbitals. The Fig. S4 shows the graphic representation of the HOMO and LUMO of the studied complexes. The HOMO's energy for complexes 1-3 are $-0,28600 \mathrm{u},-0,30083 \mathrm{u}$ and $-0,29975 \mathrm{u}$, respectively. These values are essentially identical, as are the oxidation potentials, as can be seen in Table 3. In this case the calculation data support the electrochemical results for the oxidation potentials of the complexes.

\subsection{Antimycobacterial activity}

The antimycobacterial activity of the Ru(II) compounds 1-3, and also the precursor complex and free ligands were evaluated in vitro against $M$. tuberculosis $\mathrm{H}_{37} \mathrm{Rv}$ strains by the MABA method [37]. As can be observed from the data collected in Table 4, all of the new compounds tested exhibit promising activity, with MIC values ranging from 0.4 to $6.4 \mu \mathrm{M}$. These MICs values are comparable to, or better, than those of some "second" and "first" line drugs used in current therapy $[42,43]$. Complexes 1 and 3 have stronger in vitro activity than ethambutol (MIC $5.62 \mu \mathrm{M}$ ), and complex $\mathbf{1}$ is more active than gatifloxacin (MIC $0.99 \mu \mathrm{M}$ ) [44], SQ 109 (MIC $1.56 \mu \mathrm{M})$ and TMC $207(0.81 \mu \mathrm{M})$, the last two are promising drug candidates, currently in the human clinical trials phase [42]. Complex 1 also showed activity quite similar to that of the main drug isoniazid (MIC $0.36 \mu \mathrm{M}$ ), which is the clinically used as a first-line drug in several schemes of conventional tuberculosis treatment. According to the biological results, it is clear that the coordination

Table 1

Crystallographic data and structure refinement for complexes 1-3.

\begin{tabular}{|c|c|c|c|}
\hline & 1 & 2 & 3 \\
\hline Formula & {$\left[\mathrm{RuC}_{44} \mathrm{H}_{40} \mathrm{~N}_{3} \mathrm{O}_{3} \mathrm{P}_{2}\right] \mathrm{PF}_{6} \cdot \mathrm{CH}_{3} \mathrm{OH}$} & {$\left[\mathrm{RuC}_{44} \mathrm{H}_{40} \mathrm{~N}_{3} \mathrm{O}_{3} \mathrm{P}_{2}\right]$ PF6. $\mathrm{CH}_{2} \mathrm{Cl}_{2}$} & {$\left[\mathrm{RuC}_{44} \mathrm{H}_{40} \mathrm{~N}_{3} \mathrm{O}_{3} \mathrm{P}_{2}\right] \mathrm{PF}_{6}$} \\
\hline Molecular weight & 998.81 & 1051.70 & 966.77 \\
\hline Crystal system & monoclinic & monoclinic & monoclinic \\
\hline Space group & $P 2_{1} / c$ & $P 2_{1} / c$ & $\mathrm{C} 2 / \mathrm{c}$ \\
\hline$a(\AA)$ & $12.6982(2)$ & $10.8490(1)$ & $33.7233(4)$ \\
\hline$b(\AA)$ & $20.4393(3)$ & $20.7270(3)$ & $13.8371(2)$ \\
\hline$c(\AA)$ & $17.6770(3)$ & $20.7000(3)$ & $20.5792(2)$ \\
\hline$\beta\left({ }^{\circ}\right)$ & 109.775(1) & $97.0040(10)$ & $122.720(1)$ \\
\hline Cell volume $\left(\AA^{3}\right)$ & $4317.37(12)$ & $4620.02(10)$ & $8079.15(17)$ \\
\hline$Z$ & 4 & 4 & 8 \\
\hline$D_{\text {calc }}\left(\mathrm{g} / \mathrm{cm}^{3}\right)$ & 1.537 & 1.512 & 1.590 \\
\hline$F(000)$ & 2040 & 3136 & 3936 \\
\hline$\mu\left(\mathrm{mm}^{-1}\right)$ & 0.548 & 0.626 & 0.581 \\
\hline Crystal size $\left(\mathrm{mm}^{3}\right)$ & $0.20 \times 0.19 \times 0.14$ & $0.60 \times 0.30 \times 0.15$ & $0.40 \times 0.39 \times 0.26$ \\
\hline$\theta_{\min }, \theta_{\max }\left({ }^{\circ}\right)$ & $3.17-26.80$ & $3.11-26.72$ & $2.94-26.78$ \\
\hline Reflections collected & 33371 & 33088 & 30022 \\
\hline Independent reflections $\left(R_{\text {int }}\right)$ & $9113(0.0404)$ & $9751(0.0397)$ & $8562(0.0477)$ \\
\hline Final $\mathrm{R}$ indices $[I>2 \sigma(I)]$ & $R_{1}=0.0599, w R_{2}=0.1713$ & $R_{1}=0.0511, w R_{2}=0.1482$ & $R_{1}=0.0471, w R_{2}=0.1413$ \\
\hline $\mathrm{R}$ indices (all data) & $R_{1}=0.0801, w R_{2}=0.1851$ & $R_{1}=0.0801, w R_{2}=0.1617$ & $R_{1}=0.0610, w R_{2}=0.1479$ \\
\hline Minimum and maximum residual density (e $\AA^{-3}$ ) & $-1.244,0.888$ & $-0.646,0.950$ & $-0.925,0.747$ \\
\hline
\end{tabular}


A

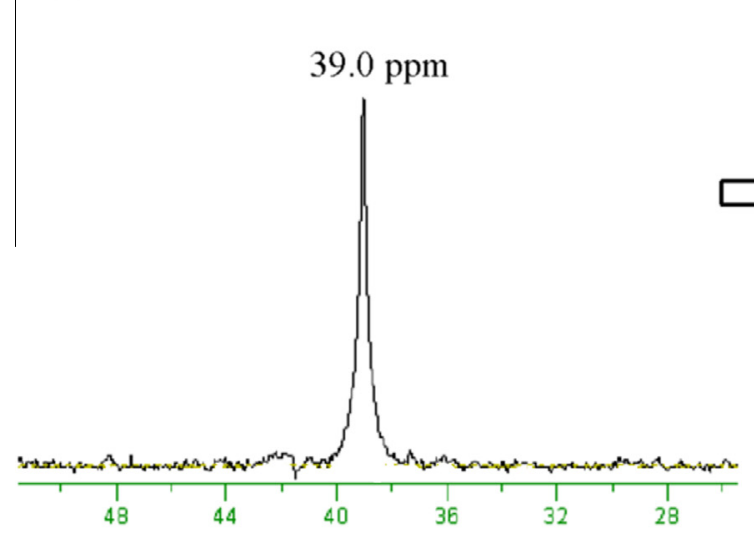

B

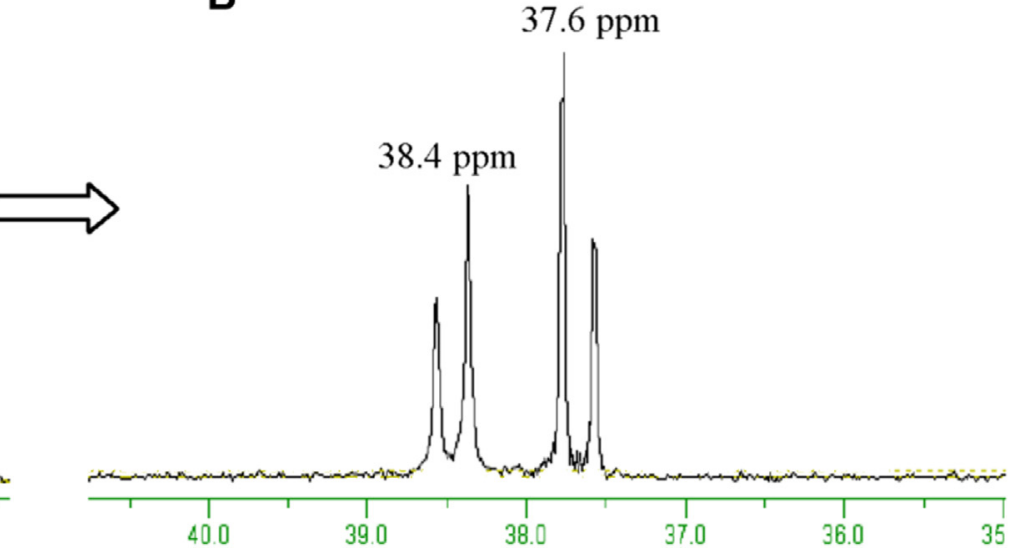

Fig. 4. ${ }^{31} \mathrm{P}\left\{{ }^{1} \mathrm{H}\right\}$ NMR spectra of complex 3 (A) $\mathrm{CH}_{2} \mathrm{Cl}_{2} / \mathrm{D}_{2} \mathrm{O}$ capillary and (B) $\mathrm{CDCl}_{3}$.

Table 2

${ }^{31} \mathrm{P}\left\{{ }^{1} \mathrm{H}\right\}$ NMR data for complexes 1-3.

\begin{tabular}{lll}
\hline Compound & ${ }^{31} \mathrm{P}\left\{{ }^{1} \mathrm{H}\right\}$ & $\left({ }^{2} J_{\mathrm{P}-\mathrm{P}} / \mathrm{Hz}\right)$ \\
\hline $\mathbf{1}^{\mathrm{a}}$ & $43.4(\mathrm{~d}) ; 41.5(\mathrm{~d})$ & 32 \\
$\mathbf{2}^{\mathrm{a}}$ & $50.3(\mathrm{~d}) ; 47.0(\mathrm{~d})$ & 32 \\
$\mathbf{3}^{\mathrm{a}}$ & $39.0(\mathrm{~s})$ & - \\
$\mathbf{3}^{\mathrm{b}}$ & $38.4(\mathrm{~d}) ; 37.6(\mathrm{~d})$ & 32 \\
\hline
\end{tabular}

a In $\mathrm{CH}_{2} \mathrm{Cl}_{2} / \mathrm{D}_{2} \mathrm{O}$ capillary.

b In $\mathrm{CDCl}_{3}$.

Table 3

Cyclic voltammetry data for complexes $\mathbf{1}-\mathbf{3}^{\text {a }}$

\begin{tabular}{llll}
\hline Compound & $\mathrm{Ru}^{\mathrm{II}} / \mathrm{Ru}^{\mathrm{III}}(\mathrm{V})$ & $\mathrm{Ru}^{\mathrm{III}} / \mathrm{Ru}^{\mathrm{II}}(\mathrm{V})$ & $E_{1 / 2}(\mathrm{~V})$ \\
\hline $\mathbf{1}$ & 1.30 & 1.22 & 1.26 \\
$\mathbf{2}$ & 1.35 & 1.28 & 1.31 \\
$\mathbf{3}$ & 1.35 & 1.20 & 1.27 \\
\hline
\end{tabular}

a Conditions: $0.100 \mathrm{~V} \mathrm{~s}^{-1}, \mathrm{CH}_{2} \mathrm{Cl}_{2}, 0.1 \mathrm{~mol} \mathrm{~L}^{-1}$, TBAP.

of the ligands (2-OHnic, 6-OHnic and 3-OHpic) to ruthenium centers promoted an increase in antitubercular activity, as showed in Table 4. Despite the structural similarities of complexes 1-3, complex $\mathbf{1}$ was significantly more active than complexes $\mathbf{2}$ and $\mathbf{3}$, respectively, by a factor of sixteen and eight. Until the moment there is no clear motivation for this difference.

\subsection{Cytotoxicity activity}

The cytotoxicity $\left(\mathrm{IC}_{50}\right)$ was performed in epithelial cells (VERO) and the highest concentration of the compounds capable of allowing the viability of cells by $50 \%$ was determined. Compounds 1-3 showed a complete lack of activity against the normal cells studied with $\mathrm{IC}_{50}$ higher than $500 \mu \mathrm{g} / \mathrm{mL}$. According to Orme et al. candidates for new drugs must have an selectivity index (SI) equal to or higher than 10 , together with MIC lower than $6.25 \mathrm{mg} / \mathrm{mL}$ (or the molar equivalent) and a low cytotoxicity [45]. SI is used to estimate the therapeutic window of a drug and to identify drug candidates for further studies. Thus, the ruthenium(II) complexes 1-3 studied here, with SI values of 1282, 79 and 161, respectively, are very promising new antituberculosis drug candidates, and therefore they could be tested in the in vitro infection model [16].

\section{Conclusion}

Three complexes of ruthenium with hydroxypyridinecarboxylates ligands (2-OHnic, 6-OHnic and 3-OH-pic) were synthesized and characterized by a combination of NMR, FTIR, electrochemical, and X-ray diffraction methods. Coordination of these ligands to ruthenium occurs in a bidentate fashion, in which each one can coordinate to the metal center in different forms. The synthesized complexes presents the formula: $[\mathrm{Ru}(2-\mathrm{nicOH})(\mathrm{dppb})(\mathrm{bipy})] \mathrm{PF}_{6}(\mathbf{1})$ with $\mathrm{O}-\mathrm{O}$ chelation (via the carboxylate group and phenolate oxygen), forming a six membered chelate ring, $[\mathrm{Ru}(6-\mathrm{nicOH})(\mathrm{dppb})-$ (bipy)] $\mathrm{PF}_{6}(2)$ with an $\mathrm{O}-\mathrm{O}$ chelation by the carboxylate group, forming a four membered chelating ring and $[\mathrm{Ru}(3-\mathrm{picOH})(\mathrm{dppb})-$ (bipy) $\mathrm{PF}_{6}(3)$ with a $\mathrm{N}-\mathrm{O}$ chelation (through the pyridine nitrogen and carboxylate oxygen), forming a five membered chelate ring. The spectroscopic and the X-ray data confirm that the complexes $\mathbf{1}$ and $\mathbf{2}$ are adopting a keto tautomeric form. The biological results of antimycobacterial activity assays provided evidence that the ruthenium(II) complexes 1-3 are potential agents against mycobacterial infections mainly due to the low MIC values found and also the high selectivity against $M$. tuberculosis $\mathrm{H}_{37} \mathrm{Rv}$ when compared with normal cells.

\section{Acknowledgments}

The authors gratefully acknowledge the financial support provided by CNPq, CAPES, FAPESP, FAPERJ (Sergio de P. Machado) and FAPEMIG (G. Von Poelhsitz). R.S. Corrêa acknowledges FAPESP for the postdoctoral fellowship (2013/26559-4).

\section{Appendix A. Supplementary data}

CCDC 949664, 949663 and 949665 contains the supplementary crystallographic data for complexes 1-3, respectively. These data can be obtained free of charge via http://www.ccdc.cam.ac.uk/conts/retrieving.html, or from the Cambridge Crystallographic Data Centre, 12 Union Road, Cambridge CB2 1EZ, UK; fax: (+44) 1223336-033; or e-mail: deposit@ccdc.cam.ac.uk. Supplementary data associated with this article can be found, in the online version, at http://dx.doi.org/10.1016/j.poly.2014.08.057.

\section{References}

[1] A. Zwerling, M.A. Behr, A. Verma, T.F. Brewer, D. Menzies, M. Pai, PLoS Med. 8 (2011) e1001012.

[2] Z. Ma, C. Lienhardt, H. McIlleron, A.J. Nunn, X. Wang, Lancet 375 (2010) 2100.

[3] World Health Organization, Global Tuberculosis Report, WHO 2012.

[4] D.G. Russell, C.E. Barry III, J.L. Flynn, Science 328 (2010) 852.

[5] J. Grange, P. Mwaba, K. Dheda, M. Hoeelscher, A. Zumla, Trop. Med. Int. Health 15 (2010) 274.

[6] A. Ginsberg, M. Tuberculosis 90 (2010) 162.

[7] E.B. Wong, K.A. Cohen, W.R. Bishai, Trends Microbiol. 21 (2013) 493. 
8] L.V. Sacks, R.E. Behrman, Tuberculosis 88 (2008) S93.

[9] Y.-S. Kwon, B.-H. Jeong, W.-J. Koh, Curr. Opin. Pulm. Med. 20 (2014) 280.

[10] M. Patra, G. Gasser, N. Metzler-Nolte, Dalton Trans. 41 (2012) 6350.

[11] L.M.M. Vieira, M.V. de Almeida, M.C.S. Lourenco, F.A.F.M. Bezerra, A.P.S. Fontes, Eur. J. Med. Chem. 44 (2009) 4107.

[12] Y. Li, C. de Kock, P.J. Smith, H. Guzgay, D.T. Hendricks, K. Naran, V. Mizrahi, D.F. Warner, K. Chibale, G.S. Smith, Organometallics 32 (2013) 141.

[13] I.L. Paiva, G.S.G. de Carvalho, A.D. da Silva, P.P. Corbi, F.R.G. Bergamini, A.L.B. Formiga, R. Diniz, W.R. do Carmo, C.Q.F. Leite, F.R. Pavan, A. Cuin, Polyhedron 62 (2013) 104

[14] F.R. Pavan, G. Von Poelhsitz, F.B. do Nascimento, S.R.A. Leite, A.A. Batista, V.M. Deflon, D.N. Sato, S.G. Franzblau, C.Q.F. Leite, Eur. J. Med. Chem. 45 (2010) 598

[15] E.R. dos Santos, M.A. Mondelli, L.V. Pozzi, R.S. Correa, H.S. Salistre-de-Araujo, F.R. Pavan, C.Q.F. Leite, J. Ellena, V.R.S. Malta, S.P. Machado, A.A. Batista, Polyhedron 51 (2013) 292.

[16] F.R. Pavan, G. Von Poelhsitz, L.V.P. da Cunha, M.I.F. Barbosa, S.R.A. Leite, A.A Batista, S.H. Cho, S.G. Franzblau, M.S. de Camargo, F.A. Resende, E.A. Varanda, C.Q.F. Leite, PLoS One 8 (2013) e64242.

[17] G.G.S. Leite, L.C. Baeza, A.A. Batista, M.I.F. Batista, F.R. Pavan, C.Q.F. Leite, J.L. Silva, R.D.C. Hirata, M.H. Hirata, R.F. Cardoso, Int. J. Microbiol. Res. 5 (2013) 6.

[18] P. Brun, A. Dean, V. Di Marco, P. Surajit, I. Castagliuolo, D. Carta, M.G. Ferlin, Eur. J. Med. Chem. 62 (2013) 486.

[19] W.O. Foye, J.M. Kauffman, Chim. Ther. 2 (1967) 462.

[20] V.B. Di Marco, A. Dean, M.G. Ferlin, R.A. Yokel, H.T. Li, A. Venzo, G.G. Bombi, Eur. J. Inorg. Chem. (2006) 1284.

[21] Y.F. Yue, W. Sun, E.Q. Gao, C.J. Fang, S. Xu, C.H. Yan, Inorg. Chim. Acta 360 (2007) 1466.

[22] S.M.O. Quintal, H.I.S. Nogueira, V. Felix, M.G.B. Drew, J. Chem. Soc., Dalton Trans. (2002) 4479.

[23] J. Miklovic, P. Segl'a, D. Miklos, J. Titis, R. Herchel, M. Melnik, Chem. Pap. 62 (2008) 464.

[24] S.M.O. Quintal, H.I.S. Nogueira, V. Felix, M.G.B. Drew, Polyhedron 21 (2002) 2783.

[25] E. Kiss, K. Petrohan, D. Sanna, E. Garribba, G. Micera, T. Kiss, Polyhedron 19 (2000) 55.

[26] A. Cuin, A.C. Massabni, C.Q.F. Leite, D.N. Sato, A. Neves, B. Szpoganicz, M.S. Silva, A.J. Bortoluzzi, J. Inorg. Biochem. 101 (2007) 291.

[27] V.B. Di Marco, A. Tapparo, A. Dolmella, G.G. Bombi, Inorg. Chim. Acta 357 (2004) 135.

[28] S.L. Queiroz, A.A. Batista, G. Oliva, M. Gambardella, R.H.A. Santos, K.S. MacFarlane, S.J. Rettig, B.R. James, Inorg. Chim. Acta 267 (1998) 209.

[29] Enraf-Nonius Collect, Nonius BV, Delft, The Netherlands 1997-2000.
[30] Z. Otwinowski, W. Minor, Macromolecular Crystallography, Part A, Academic Press, New York, 1997.

[31] G.M. Sheldrick, SHELXS-97. Program for Crystal Structure Resolution in: University of Göttingen, Göttingen, Germany, 1997.

[32] G.M. Sheldrick, SHELXS-97. Program for Crystal Structures Analysis in: University of Göttingen, Göttingen, Germany, 1997.

[33] P. Coppens, L. Leiserow, D. Rabinovi, Acta Crystallogr. 1035 (1965) 18.

[34] L.J. Farrugia, J. Appl. Crystallogr. 30 (1997) 527.

[35] Gaussian 09, R.A., M.J. Frisch, G.W. Trucks, H.B. Schlegel, G.E. Scuseria, M.A. Robb, J.R. Cheeseman, G. Scalmani, V. Barone, B. Mennucci, G. A. Petersson, H. Nakatsuji, M. Caricato, X. Li, H.P. Hratchian, A.F. Izmaylov, J. Bloino, G. Zheng, J.L. Sonnenberg, M. Hada, M. Ehara, K. Toyota, R. Fukuda, J. Hasegawa, M Ishida, T. Nakajima, Y. Honda, O. Kitao, H. Nakai, T. Vreven, J.A. Montgomery, Jr., J.E. Peralta, F. Ogliaro, M. Bearpark, J.J. Heyd, E. Brothers, K.N. Kudin, V. N. Staroverov, R. Kobayashi, J. Normand, K. Raghavachari, A. Rendell, J.C. Burant, S.S. Iyengar, J. Tomasi, M. Cossi, N. Rega, J.M. Millam, M. Klene, J.E. Knox, J.B. Cross, V. Bakken, C. Adamo, J. Jaramillo, R. Gomperts, R.E. Stratmann, O. Yazyev, A.J. Austin, R. Cammi, C. Pomelli, J.W. Ochterski, R.L. Martin, K. Morokuma, V.G. Zakrzewski, G.A. Voth, P. Salvador, J.J. Dannenberg, S. Dapprich, A.D. Daniels, Ö. Farkas, J.B. Foresman, J.V. Ortiz, J. Cioslowski, D.J. Fox, Gaussian Inc, Wallingford CT, 2009.

[36] J.C. Palomino, A. Martin, M. Camacho, H. Guerra, J. Swings, F. Portaels Antimicrob. Agents Chemother. 46 (2002) 2720.

[37] L.A. Collins, S.G. Franzblau, Antimicrob. Agents Chemother. 1004 (1997) 41.

[38] W.J. Geary, Coord. Chem. Rev. 7 (1971) 81.

39] M.O Santiago, A.A. Batista, M.P. de Araujo, C. Donnici, I.D. Moreira, E.E. Castellano, J. Ellena, S. dos Santos, S.L. Queiroz, Transition Met. Chem. 30 (2005) 170.

[40] E.M.A. Valle, F.B. do Nascimento, A.G. Ferreira, A.A. Batista, M.C.R. Monteiro, S.D. Machado, J. Ellena, E.E. Castellano, E.R. de Azevedo, Quim. Nova 31 (2008) 807.

[41] M.C.R. Monteiro, F.B. Nascimento, E.M.A. Valle, J. Ellena, E.E. Castellano, A.A. Batista, S.D. Machado, J. Braz. Chem. Soc. 2010 (1992) 21.

[42] V.M. Reddy, L. Einck, K. Andries, C.A. Nacy, Antimicrob. Agents Chemother. 54 (2010) 2840.

[43] R.P. Tripathi, N. Tewari, N. Dwivedi, V.K. Tiwari, Med. Res. Rev. 25 (2005) 93.

[44] D. Sriram, P. Yogeeswari, M. Dinakaran, R. Thirumurugan, J. Antimicrob. Chemother. 59 (2007) 1194.

[45] I. Orme, J. Secrist, S. Anathan, C. Kwong, J. Maddry, R. Reynolds, A. Poffenberger, M. Michael, L. Miller, J. Krahenbuh, L. Adams, A. Biswas, S. Franzblau, D. Rouse, D. Winfield, J. Brooks, Tuberculosis Drug Screening, P. Antimicrob. Agents Chemother. 2001 (1943) 45. 